\title{
Production of Single Cell Microbial Protein and its Use as Protein Source in Broiler Ration
}

\author{
Faheem Ahmed Khan ${ }^{1 *}$, Sarzamin Khan², Qurat-ul-Ain ${ }^{3}$, Saqib Ishaq ${ }^{1}$, \\ Muhammad Salman', Abdul Rehman', Ikram Ullah ${ }^{4}$, Kalsoom ${ }^{5}$ and Johar Jamil ${ }^{5}$ \\ ${ }^{1}$ Department of Microbiology and Biotechnology, Abasyn University, Peshawar, Khyber \\ Pakhtunkhwa, Pakistan \\ ${ }^{2}$ Department of Poultry Sciences, Faculty of Animal Husbandry, Agricultural University, \\ Peshawar, Khyber Pakhtunkhwa, Pakistan \\ ${ }^{3}$ Department of Pharmacy, Abasyn University Peshawar, Khyber Pakhtunkhwa, Pakistan \\ ${ }^{4}$ Department of Medical Laboratory Technology, University of Haripur, Khyber \\ Pakhtunkhwa, Pakistan \\ ${ }^{5}$ Department of Microbiology, University of Swabi, Khyber Pakhtunkhwa, Pakistan
}

\begin{abstract}
A B S T R A C T
Malnutrition is a rising issue in most of the developing countries. To overcome this problem, it is necessary to explore alternate methods for production of non-conventional proteins utilizing the available cheap sources. The indigenous Saccharomyces cerevisiae were isolated from different fruit samples, identified by conventional polymerase chain reaction (PCR) and were characterized for production of single cell microbial protein (SCMP). Out of 60 different fruit samples, a total number of confirmed S. cerevisiae isolates were 1, 2 and 1 from orange (Citrus sinensis), grapes (Vitis), and peach (Prunus persica), respectively. Utilizing yeast extract, peptone and dextrose maximum biomass was produced by $S$. cerevisiae isolate recovered from peach (SCP-1) i.e. $4.83 \mathrm{~g} / 1$. Using isolate SCP-1 higher biomass of $S$. cerevisiae was produced on sugarcane molasses $(6.42 \mathrm{~g} / \mathrm{l})$ followed by orange peels. Microbial biomass produced on the sugarcane molasses was rich in crude proteins $(56 \%)$ followed by that from orange peels. Highest percentage of alanine (24.72\%) and aspartic acid (17.83\% and $14.57 \%)$ were observed in dried single cell microbial protein produced on sugarcane molasses, orange peels and apple waste, respectively. Soybean meal protein source in broilers ration was replaced by SCMP. The level of antibody titre against Newcastle Disease Vaccine was significantly higher $(\mathrm{p} \leq 0.05)$ than all treated groups. Higher antibody titre was recorded for group $\mathrm{C}(6 \mathrm{~g} / \mathrm{Kg})(\mathrm{HI} \geq 1: 64)$ followed by group B $(4 \mathrm{~g} / \mathrm{Kg})(\mathrm{HI} \geq 1: 32)$ and Group A $(2 \mathrm{~g} / \mathrm{Kg})(\mathrm{HI} \geq 1: 8)$ while antibody titre was lower for control group D. Replacement of soybean meal with SCMP did not affect the level of liver enzymes. All the tested liver enzymes were observed to be present in the normal range in all the treated groups A, B, C and D. Feed conversion ratio was not affected in the treated groups and an average FCR of 1.6 was observed in all groups. From the present study it is concluded that indigenous $S$. cerevisiae can be isolated from different sources and can be used as a source of SCMP in broilers ration to enhance their performance, immunity against pathogenic microbes for production of quality meat.
\end{abstract}

\begin{tabular}{|c|}
\hline Article Information \\
\hline Received 16 November 2018 \\
\hline Revised 29 May 2019 \\
\hline Accepted 02 October 2019 \\
\hline Available online 19 March 2021 \\
\hline Authors' Contribution \\
\hline $\begin{array}{l}\text { FAK performed the experiments. NB } \\
\text { contributed in in vitro experiments. } \\
\text { SK provided birds and helped in } \\
\text { experimental work. QA and NA } \\
\text { helped in prepration. }\end{array}$ \\
\hline Key words \\
\hline $\begin{array}{l}\text { Saccharomyces cerevisiae, Polymerase } \\
\text { chain reaction, Single cell microbial } \\
\text { protein, Amino acids }\end{array}$ \\
\hline
\end{tabular}

\section{INTRODUCTION}

$\mathrm{M}$ icrobial proteins which are also called as single cell protein is produced by growing different organisms like algae, bacteria, fungi and yeast using different agricultural processing waste (Nasseri et al., 2011). Hence, on the one hand, single cell protein is the more valuable optional protein than the animal protein due to the presence of large amount of protein contents and, on the other hand, these are economical and environment-friendly, as

\footnotetext{
Corresponding author: faheemdurani@gmail.com 0030-9923/2021/0003-0875 \$ 9.00/0

Copyright 2021 Zoological Society of Pakistan
}

different agricultural wastes have been utilized for their production (Saima et al., 2008, Jamuna and Ramakrishna, 1989). Further, they contain better levels of essential amino acids and chemicals as compared to the vegetable protein (Nasseri et al., 2011).

There is also a robust struggle between human beings and livestock for the available plant and animal protein sources. That's why animal and poultry feed industries are in great trouble due to the availability of costly feed ingredients which are used as protein supplementation. As a non-conventional protein source single cell protein in dry form can be effectively used as a replacement protein in poultry and animal ration (Gad et al., 2010; Lyutskanov et al., 1990). 
Some yeast species including $S$. cerevisiae, $S$. kluyveri, S. ludwigii and S. exigus are found on most of the citrus fruits which are acidic in nature having $\mathrm{pH}$ 3-4 with tremendous sugar contents from where these can be easily isolated (Arias et al., 2002; Qureshi et al., 2007).

The cell wall of S. cerevisiae accounts for $20 \%$ of the cell weight (Walker, 1998). The $\beta$-glucan has been made up of about $55-65 \% \mathrm{w} / \mathrm{w}$ of the cell walls, consisting of both long chains of $\beta-1,3$-glucan and short chains of $\beta-1,6$ glucan (Klis et al., 2002). It has also been reported that glucans exhibit many practical implications with medicinal properties such as antitumor, antimicrobial and antioxidant activities as well as mycotoxin absorption (Magnani et al., 2011; Chen and Seviour, 2007).

Distinctive microorganisms, including bacteria, fungi and yeast have been used as a hotspot for the creation of single cell protein (Chell, 1997), among them a few types of yeast including $S$. cerevisiae are the most imperative as these give concentrated development, with ideal nourishment supply under ideal conditions (Ghanem et al., 1986). What's more, can be effectively reaped in light of their vast cellular mass (Wolf et al., 2003). In fermentation industry different glucose rich substrates are used which support the growth of $S$. cerevisiae. After successful fermentation, the process is ceased and yeast is harvested by centrifugation and filtration which in dry form can effectively be used as food and feed for humans, animals, and poultry consumption. For improvement single cell protein are digested by mechanical disruption, autolysis, and enzymatic treatment (Curran, et al., 1990; Nasseri et al., 2011).

Different types of wastes are produced by agricultural activities and food processing plants which are rich in organic matter and if present in the environment can increase biochemical oxygen demand. These wastes can be utilized to produce valuable products. Three different types of agricultural waste materials including orange peels, apple waste, and sugar cane molasses were studied for the production of single cell protein utilizing indigenous S. cerevisiae. These wastes have the potential nutrients and elements which support the growth of a variety of microorganisms (Haddadin et al., 1999; Paul et al., 2002).

Our country solely depends on the import of $S$. cerevisiae for the animal and poultry industries in the form of inactive dry yeast. It is needed to isolate indigenous $S$. cerevisiae and to explore the potential of various agriculture wastes for its production, keeping in mind the end goal to satisfy national prerequisites and to spare remote trade. In the year 2024, the estimated world population will be about 8 billion. This expected increase in human population can lead to the malnutrition problems due to protein deficiency for humans and animals consumption. So, it is demanded to explore alternate methods for production of single cell microbial protein to overcome protein deficiency in broilers feed replacing one of the existing protein source. The present study was designed to isolate indigenous $S$. cerevisiae from different fruit samples and to grow them, utilizing some of the available cheap sources as substrate and to replace them one of the existing protein source in broilers feed.

\section{MATERIAL AND METHODS}

\section{Isolation and identification of $\mathrm{S}$. cerevisiae}

Desired microorganism was isolated from different fruit samples on yeast extract peptone dextrose agar. To suppress the growth of unwanted bacteria the media was supplemented with $30 \mathrm{mg} / \mathrm{ml}$ erythromycin (Guimarães et al., 2006). After Inoculation media plates were incubated at $30^{\circ} \mathrm{C}$ for $24 \mathrm{~h}$. On the basis of colony morphology, isolated colonies were subjected to microscopic examination for identification of budding yeast (Ochei and Kolhatkar, 2000). Microscopically identified yeast samples were then subjected to biochemical identification on the basis of their taxonomic classification (Barnett et al., 1983; Kurtzman et al., 2011). Conventionally the PCR products were analyzed on $1 \%$ agarose gel.

\section{Screening of isolates for biomass production}

For biomass production, $200 \mathrm{ml}$ yeast extract peptone dextrose broth (YEPD Oxide) was prepared at $\mathrm{pH} 5$ in 250 $\mathrm{ml}$ Erlenmeyer flasks. Each flask was inoculated with 5 $\mathrm{ml}$ of isolated $S$. cerevisiae cultures, plugged with cotton wool and incubated in a shaking incubator at $150 \mathrm{rpm}$ at $30^{\circ} \mathrm{C}$. After $48 \mathrm{~h}$ fermentation process was stopped and yeast cells were harvested by centrifugation and filtration. Harvested yeast cells were then dried at $70^{\circ} \mathrm{C}$ for $48 \mathrm{~h}$ and weighed in a pre-dried pre-weighted aluminum pain.

\section{Collection and preparation of substrates}

Three agro-industrial wastes i.e. orange peels, apple wastes and sugar cane molasses were obtained from a local market. After collection, the apple wastes and orange peels were thoroughly washed with sterile distilled water to remove the dirt and adherent chemicals. These were then cut into small pieces, boiled for $10 \mathrm{~min}$ in a specific amount of distilled water and then blended in a clean blender to make a slurry.

The slurry materials obtained were then treated with chemicals to obtain more available sugars from complex polysaccharides following the procedure as described by Bacha et al., 2011. The sugar cane molasses was used as such with no chemical treatment. Substrates obtained from all three sources were then filtered through mesh size 40 to remove any large particles. In the form of solutions, 
these substrates were then used to grow $S$. cerevisiae for production of SCMP.

\section{Proximate analysis of substrates}

All the three waste materials were analyzed for the presence of moistures, crude fats, crude proteins, ash contents, crude fibers and carbohydrates according to their respective procedures (Association of Official Analytical Chemist, 2006).

Optimization of laboratory parameters for maximum production of indigenous $\mathrm{S}$. cerevisiae on apple waste and orange peels

For optimum production, different parameters such as $\mathrm{pH}$, temperature, shaking and glucose concentration were optimized in the media containing 10\% substrate (Apple waste/Orange peels), $1 \%$ yeast extract and $0.5 \%$ ammonium nitrate using the statistical approach of response surface methodology. For graphical and statistical analysis JMP 12.1.0 software was used in the study. A $2^{4}$ rotatable central composite design was adopted consisted of 26 sets of experiments with different combinations of variables. To confirm the production of optimum microbial biomass, a new experiment was performed under the optimum conditions as predicted by the model (Jalasutram et al., 2013; Khan et al., 2016, 2018).

\section{Biomass production utilizing prepared substrate}

For three different substrates i.e. apple waste, orange peels and sugarcane molasses, yeast cells were cultured in 3 different jars each with a volume size of $1 \mathrm{~L}$. All jars were filled with optimized fermenting media i.e. jars containing apple waste, $10 \%$ substrate, $2.7 \%$ glucose, $1 \%$ yeast extract and $0.5 \%$ ammonium nitrate; the jars containing orange peels, $10 \%$ substrate, $2.36 \%$ glucose, $1 \%$ yeast extract and $0.5 \%$ ammonium nitrate; while jars containing sugar cane molasses, $10 \%$ substrate, $0.5 \%$ ammonium nitrate and $1 \%$ yeast extract was added and volume was adjusted to $700 \mathrm{~mL}$ with distilled water. All jars were plugged with cotton wool and sterilized at $121^{\circ} \mathrm{C}$ for $20 \mathrm{~min}$. After sterilization $\mathrm{pH}$ of the media was adjusted to 5 and all jars were inoculated with a $5 \mathrm{~mL}$ inoculum of $S$. cerevisiae aseptically. Then all jars were incubated at $32^{\circ} \mathrm{C}$ for $72 \mathrm{~h}$ in a shaking incubator at $150 \mathrm{rpm}$. After a subsequent growth, the incubation process was stopped. Microbial biomass was then harvested by centrifugation, washing with sterile distilled water and then vacuum filtration through filter paper of $0.45 \mu \mathrm{m}$ pore size (Khan et al., 2018).

\section{Determination of dry biomass}

Yeast cakes obtained on a sterile filter paper were then dried into a pre-dried and pre-weighed aluminum pan to a constant weight in a hot air oven at $70^{\circ} \mathrm{C}$ for $48 \mathrm{~h}$ (Ojokoh and Uzeh, 2005).

\section{Proximate analysis of dry single cell microbial protein (SCMP)}

Dried single cell proteins obtained by growing $S$. cerevisiae on orange peels, apple waste and sugar cane molasses were subjected to analysis of crude proteins, carbohydrates, crude fats, and ash contents on the basis of dry matter, according to their respective procedures (Association of Official Analytical Chemist, 2006).

\section{Amino acid profile of produced single cell protein}

For amino acid profile dried single cell proteins were crushed, acid hydrolyzed and the amino acid profile was measured by a High Performance Liquid Chromatography (Shimadzu LC-20A) automatic amino acid analyzer with post-column derivatization, using Ortho Phthalaldehyde (OPA) as a fluorescent agent (Woodward et al., 2007). All experiments were performed in triplicates and mean values were recorded.

\section{Effect of replacement of soybean meal with dry SCMP} in broilers ration

A total of 120 , one-week old broiler chicks were obtained from the local market. All birds were divided into four groups A, B, C, and D and each group was divided into three replicates with 10 birds per each replicate so that each group contain 30 birds. In the ration of treated groups soybean meal was replaced with 2, 4 and $6 \mathrm{~g} /$ $\mathrm{kg}$ of produced SCMP, respectively, while group D was treated as control with no protein replacement as shown in Supplementary Table I. At the start, all birds were vaccinated for Newcastle disease. After 5 weeks blood samples were collected from all groups and were analyzed for antibody titre against Newcastle Disease and liver function tests. Birds in groups were also analyzed for feed conversion ratio and mortality.

\section{Statistical analysis}

In last data was statistically analyzed by analysis of variance (ANOVA).

\section{RESULTS}

Saccharomyces cerevisiae isolate and biomass production

A total of four isolates, 01 from oranges, 02 from grapes and 01 from peaches were identified $S$. cerevisiae microscopically biochemically and a301 bp per band. The identified isolates were named as SCP-1, SCO-1, SCG-1 and SCG-2; isolated from peaches, oranges, and grapes respectively. 
Table I. Proximate analysis of processed agro-industrial wastes.

\begin{tabular}{llllll}
\hline & Moisture contents \% & Crude proteins \% & Carbohydrates \% & Crude fats \% & Ash contents \% \\
\hline Orange peels & $51.83 \pm 4.06$ & $7.67 \pm 2.13$ & $30.48 \pm 3.16$ & $2.22 \pm 1.92$ & $7.82 \pm 2.1$ \\
Sugarcane molasses & $21.35 \pm 1.93$ & $2.08 \pm 0.13$ & $65.14 \pm 4.11$ & $0 \%$ & $11.43 \pm 1.93$ \\
Apple waste & $76.52 \pm 4.23$ & $1.06 \pm .41$ & $18.08 \pm 2.31$ & $0.83 \pm 0.03$ & $3.51 \pm 0.2$ \\
\hline
\end{tabular}

In the table, each value is the mean standard deviation from three replicates.

Maximum biomass was produced by isolate SCP-1 (4.83 g/l $\pm 1.63 \%)$ followed by SCO-1 (4.56 g/l $\pm 1.21 \%)$ and SCG-1 (4.33 g/l $\pm 1.67 \%)$ while low biomass was produced by isolate SCG-2 (3.82 $\mathrm{g} / 1 \pm 0.83 \%)$.

Proximate analysis of processed agro-industrial wastes

Table I shows proximate compositions of all three agricultural waste materials. The sugar cane molasses and orange peels were observed to contain a greater amount of carbohydrates i.e. $65.14 \pm 4.11 \%$ and $30.48 \pm 3.16 \%$ respectively and ash contents (minerals and vitamins) i.e. $11.43 \pm 1.93 \%$ and $7.82 \pm 2.10 \%$ respectively as compared to apple waste. A better quantity of carbohydrates in orange peels than apple waste is due to the presence of complex polysaccharides in orange peels, which are then converted into simple sugar by chemical treatment. Orange peels were found to contain a significant amount of crude proteins and crude fats i.e. $7.67 \pm 2.13 \%$ and 2.22 $\pm 1.92 \%$ respectively, as compared to sugar cane molasses and apple wastes.

\section{Biomass production utilizing different agro-industrial waste materials}

According to the present central composite design, utilizing apple waste maximum biomass $(5.04 \mathrm{~g} / \mathrm{L})$ was obtained at glucose concentration $2.7 \%, \mathrm{pH} 5$, shaking at $150 \mathrm{rpm}$ at $32^{\circ} \mathrm{C}$. For orguge pcels maximum microbial mass $(5.86 \mathrm{~g} / \mathrm{L})$ was produced at $\mathrm{pH} 5$, glucose concentration $2.36 \%$, shaking at $150 \mathrm{rpm}$ at $32^{\circ} \mathrm{C}$.

Figure 1 shows biomass production after $48 \mathrm{~h}$ of incubation. Maximum growth of $S$. cerevisiae was observed in flasks containing sugar cane molasses as a substrate $(6.42 \mathrm{~g} / 1 \pm 1.23)$, followed by orange peels $(5.86$ $\mathrm{g} / \mathrm{l} \pm 0.98$ ), while a minimum growth was observed in a flask containing apple waste as a substrate.

Figure 2 shows proximate analysis of single cell protein on the basis of dry matter. The highest percentage of crude protein $(56.11 \pm 3.89)$ was observed in single cell protein obtained from sugar cane molasses as compared to orange peels $(50.67 \pm 3.41)$ and apple waste $(44.65$ \pm 2.12 ). On the other hand, biomass produced on apple waste was rich in carbohydrates $(47.67 \pm 2.73)$ followed by orange peels and sugar cane molasses.



Fig. 1. Saccharomyces cerevisiae biomass production on different substrates at different time interval.

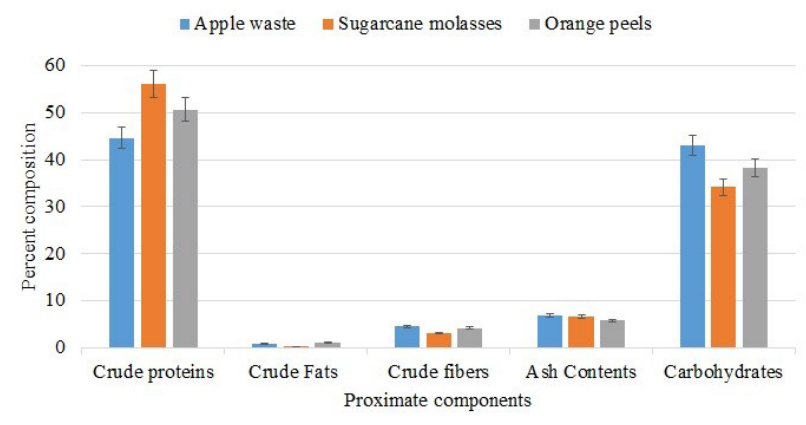

Fig. 2. Proximate analysis of single cell microbial protein.

Amino acid profile of dry SCMP

Amino acid composition along with chromatogram of produced dry single cell protein is presented in Table II. The results show that there were substantial differences in the amino acid composition of single cell protein obtained from different agricultural wastes. The highest percentage of alanine $(24.72 \pm 2.79)$, glycine $(4.15 \pm 0.48)$ and arginine $(13.72 \pm 3.39)$ were observed in dried microbial single cell protein produced on sugar cane molasses followed by orange peels and apple waste.

Effect of replacement of soybean meal protein source with dry SCMP in broilers ration

Data regarding antibody titre, mortality and liver function tests in broilers is presented in Table III. The level of antibody titre was significantly $(\mathrm{p} \leq 0.05)$ higher within all treated groups $\mathrm{A}, \mathrm{B}$, and $\mathrm{C}$ as compared to control 
group D. Higher antibody titre was recorded for group C $(\mathrm{HI} \geq 1: 64)$ followed by group $\mathrm{B}(\mathrm{HI} \geq 1: 32)$ and Group $A$ $(\mathrm{HI} \geq 1: 8)$ while antibody titre was lower for control group D. Replacement of soybean meal with single cell microbial protein did not affect the level of liver enzymes and were not significant within the groups with p. value of 0.2894 , 0.2859 and 0.0627 for ALT, AST and ALP, respectively. All the tested liver enzymes were observed to be present in the normal range in all the treated groups A, B, C and D. Feed conversion rate was not affected in the treated groups and an average FCR of 1.6 was observed in all the treated groups. In all treated groups A, B, C and D meat colour was bright pink with no variations. Mortality was not significantly affected in all the treated groups. Results disclosed that higher mortality was observed in control group $\mathrm{D}$, while lower mortality was observed in Group C in which maximum soybean meal was replaced with single cell microbial protein.

\section{DISCUSSION}

The beneficial use of $S$. cerevisiae as protein source and as probiotic for human, animal and poultry are widely documented by recent studies that have explained different mechanisms for its isolation, identification and for its use as single cell protein and as probiotics. The main criteria for isolation of indigenous $S$. cerevisiae is its maximum growth on various substrates to produce protein rich biomass and to resist the low $\mathrm{pH}$ of the stomach as well as bile salt in intestine when used as probiotic (Gueimonde and Salminen, 2006).

For isolation of indigenous $S$. cerevisiae strains from different fruit samples, the samples were processed aseptically and yeast strains were grown on artificial media supplemented with erythromycin to suppress bacterial contamination and the same method was adopted by Guimarães et al. (2006) for isolation and characterization of yeast.

Isolation of $S$. cerevisiae from different fruit samples revealed its presence normally on different fruits while isolation of maximum $S$. cerevisiae isolates from grapes reveals its significance for the production of wild-type wine utilizing untreated grapes (Son et al., 2008). As the main concern was maximum biomass production and the same was produced by $S$. cerevisiae isolated from peach, in this regard the isolate named as SCP-1 was subjected to biomass production utilizing various agro-industrial wastes under optimized conditions. Šuranská et al. (2016) also used grape berries and spontaneously fermented musts to isolate, identify and characterize indigenous $S$. cerevisiae using polymerase chain reaction.

Table II. Amino acid profile of dry SCMP produced on different agro-industrial wastes.

\begin{tabular}{lllll}
\hline \multirow{2}{*}{ Amino acids } & \multicolumn{3}{c}{ Percent concentration } \\
\cline { 3 - 5 } & & Apple waste & $\begin{array}{l}\text { Sugar cane } \\
\text { molasses }\end{array}$ & $\begin{array}{l}\text { Orange } \\
\text { peels }\end{array}$ \\
\hline 1 & Aspartic acid & $14.57 \pm 1.79$ & $0.75 \pm 0.1$ & $17.82 \pm 3.97$ \\
2 & Threonine & $4.87 \pm 1.03$ & $5.25 \pm 1.24$ & $4.50 \pm 0.26$ \\
3 & Serine & $12.89 \pm 3.08$ & $3.83 \pm 0.62$ & $2.92 \pm 0.17$ \\
4 & Glycine & $2.49 \pm .11$ & $4.15 \pm 0.48$ & $2.88 \pm 0.21$ \\
5 & Alanine & $11.37 \pm .95$ & $24.72 \pm 2.79$ & $12.43 \pm 1.13$ \\
6 & Valine & $5.76 \pm 1$ & $9.10 \pm 2.22$ & $4.64 \pm 0.11$ \\
7 & Methionine & $5.66 \pm 1.3$ & $7.85 \pm 0.61$ & 0 \\
8 & Isoleucine & $8.24 \pm 1.61$ & $6.02 \pm 1.14$ & $4.92 \pm 0.21$ \\
9 & Leucine & $14.47 \pm 2.34$ & $2.63 \pm 0.21$ & $15.90 \pm 2.33$ \\
10 & Tyrosine & $4.59 \pm 0.81$ & $2.53 \pm 0.71$ & $4.52 \pm 0.19$ \\
11 & Phenylalanine & $3.32 \pm 0.49$ & $14.38 \pm 2.16$ & $1.91 \pm 0.24$ \\
12 & Histidine & $2.08 \pm 0.61$ & $1.14 \pm 0.26$ & $1.34 \pm 0.13$ \\
13 & Lysine & $8.79 \pm 1.33$ & $1.83 \pm 0.41$ & $2.42 \pm 0.51$ \\
14 & Arginine & $0.75 \pm 0.13$ & $13.72 \pm 3.39$ & $5.26 \pm 1.54$ \\
15 & Glutamic acid & 0 & $0.87 \pm 0.41$ & $4.69 \pm 1.21$ \\
16 & Proline & 0 & $1.14 \pm 0.83$ & $13.83 \pm 2.73$ \\
\hline & & & &
\end{tabular}

In the table each value is the mean standard deviation from three replicates.

Table III. Antibody titre, liver function tests, feed conversion ratio and mortality in broilers.

\begin{tabular}{lllllll}
\hline Groups & Average antibody titre & ALT $($ units/L) & AST( units/L) & ALP $($ units/L) & FCR & Mortality \\
\hline A & $3.66^{\mathrm{b}} \pm 0.57(\mathrm{HI} \geq 1: 8)$ & $27.66 \pm 1.5$ & $143 \pm 7.21$ & $171.67^{\mathrm{a}} \pm 13.5$ & 1.658 & $0.66^{\mathrm{ab}} \pm 0.57$ \\
$\mathrm{~B}$ & $5.66^{\mathrm{a}} \pm 1.15(\mathrm{HI} \geq 1: 32)$ & $31.33 \pm 2.08$ & $159.33 \pm 9.5$ & $143.33^{\mathrm{b}} \pm 16.8$ & 1.621 & $0.66^{\mathrm{ab}} \pm 1.15$ \\
$\mathrm{C}$ & $6.33^{\mathrm{a}} \pm 0.64(\mathrm{HI} \geq 1: 64)$ & $28.33 \pm 3.05$ & $155.33 \pm 12.5$ & $176.67^{\mathrm{a}} \pm 4.16$ & 1.612 & $0^{\mathrm{b}}$ \\
$\mathrm{D}$ & $3.33^{\mathrm{b}} \pm 1.52(\mathrm{HI} \geq 1: 8)$ & $29.33 \pm 2.08$ & $154 \pm 4.16$ & $167.67^{\mathrm{ab}} \pm 19.5$ & 1.641 & $1.66^{\mathrm{a}} \pm 0.57$ \\
$\mathrm{P}=0.05$ & 0.0189 & 0.2849 & 0.2859 & 0.0427 & 0.1631 & 0.026 \\
\hline
\end{tabular}

Group A, Soybean meal was replaced with $2 \mathrm{~g} / \mathrm{kg}$ single cell microbial protein; Group B, Soybean meal was replaced with $4 \mathrm{~g} / \mathrm{kg}$ single cell microbial protein; Group C, Soybean meal was replaced with $6 \mathrm{~g} / \mathrm{kg}$ single cell microbial protein and group; D, No feed replacement; ALT, Alanine aminotransferase; AST, Aspartate aminotransferase; ALP, Alkaline phosphatase. 
Yeast have the ability to grow on a variety of substrates, and to upgrade their protein contents (Babu and Ilyas, 2017). For the said purpose different agro-industrial wastes were used to produce protein rich biomass. Agricultural processing wastes contain complex polysaccharides, which are then converted into simple sugars for easy uptake by microorganisms. When analyzed for their proximate composition selected wastes as substrate were different from each other; the mentioned differences are expected to be due to different varieties of plant species, environmental factors and soil physico-characteristics as discussed by (Bárta, 2002). In the present study sugarcane molasses and orange peels were rich in carbohydrates and ash contents. A better quantity of carbohydrates in orange peels than apple waste is due to the presence complex polysaccharides in orange peels, which are then converted into simple sugar by chemical treatment.

$S$. cerevisiae is a great source of single cell protein, it can be used as safe food and do not cause any health hazard to humans if consumed. In the present study elevated $S$. cerevisiae biomass production was observed in sugarcane molasses which reveals the significance of high carbohydrate and mineral contents in sugar cane molasses and the same support the findings of (Bacha et al., 2011) and (Lenihan et al., 2010). The possible reason of lower growth utilizing orange peels might be due to higher crude fat contents including limonene which may affect digestion process and prevent yeast cells from taking essential nutrients for growth which support the findings of (Talebnia, 2008). Single cell microbial protein when analyzed was rich in crude protein which corroborates the findings of (Ojokoh and Uzeh, 2005). They observed $35.5 \%$ of crude proteins from single cell protein obtained by growing $S$. cerevisiae on papaya extract. For detection of optimum incubation period S. cerevisiae isolate SCP1 was inoculated on different substrates and incubated from 0-48 h. Maximum growth was observed at $42 \mathrm{~h}$ of incubation. For the same purpose Babu and Ilyas, 2017 incubated $S$. cerevisiae isolated from mangrove sediment, they noted optimum growth after $48 \mathrm{hrs}$ of incubation with $0.5 \%$ yeast extract, decrease in time may be due to optimum medium for the growth of $S$. cerevisiae with $1 \%$ yeast extract and $0.5 \%$ ammonium nitrate as a source of nitrogen. In a similar study (Nofemele et al., 2012) mentioned that yeast growth and ethanol production was increased with the addition of urea as nitrogen source.

When analyzed for the presence of amino acids it was observed that single cell microbial protein produced on orange peels was deficient in methionine which supports the findings of (Fred and Peterson, 1921; Kihlberg, 1972; Tannenbaum and Wang, 1975). While the single cell protein produced on apple waste and sugar cane molasses were deficient in glutamic acid and proline. The presence of optimum quantities of amino acids in produced single cell protein reveals its significance and use as an ingredient in human food as well as poultry and animal feed (Carver, 1994; Lowry et al., 1951).

No adverse effect was observed with the replacement of single cell microbial protein in broilers on internal body organs and the liver function tests as compared with control group D. $\beta-1,3$ and $\beta-1,6$ glucan along with Mannanoligosaccharide are used as the significant natural growth promoters for livestock and poultry production (Ravindra, 2000; Van et al., 2005). S. cerevisiae is considered as one of the best microbial protein. When these are added to the diet of the poultry, positively affected the poultry health (Patterson and Burkholder, 2003). Field reports concluded that yeast addition was highly effective in broilers (Cmiljanic et al., 2001; Banday and Risam, 2001). S. cerevisiae regulates the intestinal microflora and reinforces the host natural defenses (Line et al., 1998). The oligosaccharide content is approximately $50 \%$ of the total carbohydrate and improved body weight in broilers. These products have a positive effect on intestinal mucosa because due to its administration villus height was increased, in first week (Santin et al., 2001).

When soybean was replaced with single cell microbial protein in broilers ration showed a positive effect on the level of antibody titre. The titre was positively increased in the groups $\mathrm{B}$, and $\mathrm{C}$ as compared with group $\mathrm{A}$ and control group D. Antibody responses have been used as measuring parameter for detection of the immune response against an antigen (Davis and Sell, 1989). Humoral immunity was increased in the mannan oligosaccharide group in the trials of Shashidhara and Devegowda, 2003 who suggested that MOS can be used to enhance immunity. The mechanism of $\beta$-glucans in the modulation of the immune system is understood but the detailed mechanism of the effect of MOS on the humoral immune system needs to be explained. One the other hand, Cotter et al. (2000) and Raju and Devegowda (2000) conducted experiments in broilers and they reported that antibody titres against Infectious bronchitis disease vaccine (IBDV) and Newcastle disease were not enhanced by the addition of MOS in the feed.

No mortalities were reported in group $\mathrm{C}$ in which soybean meal was replaced with $6 \mathrm{~g} / \mathrm{kg}$ SCMP. The mentioned results could be due to mannan-oligosaccharides (MOS) which are used to control the growth of pathogenic bacteria in the livestock (Laegreid and Bauer, 2004). It is observed that in the presence of mannan-oligosaccharides the attachment and colonization of pathogenic bacteria to the bird's intestine is inhibited which may protect the birds from different diseases. On the other hand mannanoligosaccharides act as a nutrient to other normal flora 
which enhances the health of birds.

SCMP enhances the broilers immunity, so further increasing the health status of birds by increasing their immunity against pathogenic bacteria. Firon et al. (1983) and Oyofo et al. (1989a) observed that in the presence of mannose, attachment of Salmonella typhimurium was inhibited to the small intestine of chicks. It was also observed that when mannose was included in the drinking water of chicks, colonization of $S$. typhimurium in the cecum was reduced (Oyofo et al., 1989a, b).

\section{CONCLUSIONS}

The present study concluded that along with carbohydrates present in different agricultural processing wastes; vitamins and minerals also play a key role in the growth of indigenous $S$. cerevisiae. Single cell protein produced by growing indigenous $S$. cerevisiae on different agro-industrial wastes can be successfully utilized as protein replacement in broilers feed to combat the malnutrition problem.

\section{ACKNOWLEDGEMENT}

We kindly acknowledge financial support from the Higher Education Commission H-9 Islamabad, Pakistan throughout the study.

\section{Supplementary material}

There is supplementary material associated with this article. Access the material online at: https://dx.doi. org/10.17582/journal.pjz/20181116211131

\section{Statement of conflict of interest}

The authors declare that there is no conflict of interest.

\section{REFERENACES}

Arias, C.R., Burns, J.K., Friedrich, L.M., Goodrich, R.M. and Parish, M.E., 2002. Yeast species associated with orange juice: evaluation of different identification methods. Appl. environ. Microbiol., 68: 1955-1961. https://doi.org/10.1128/ AEM.68.4.1955-1961.2002

Association of Official Analytical Chemist. 2006. The official methods of analysis of AOAC international. The Assoc. Official Anal. Chem. Arlington, U.S.A.

Babu, M.P. and Ilyas, M.M., 2017. SCP production from Saccharomyces cerevisiae isolated from mangrove sediment. Int. J. Adv. Multidiscip. Res. 4: 1-10. https://doi.org/10.22192/ijamr.2017.04.01.001

Bacha, U., Nasir M., Khalique, A., Anjum, A. and Jabbar,
M., 2011. Comparative assessment of various agroindustrial wastes for Saccharomyces cerevisiae biomass production and its quality evaluation as single cell protein. J. Anim. Pl. Sci. 21: 844-9.

Banday, M. and Risam, K., 2001. Growth performance and carcass characteristics of broiler chicken fed with probiotics. Indian J. Poult. Sci. 36: 252-255.

Barnett, J.A., Payne R.W. and Yarrow, D., 1983. Yeasts: Characteristics and identification. Cambridge University Press.

Bárta, J., 2002. Studium vlivu dusíkatého hnojení na kvalitu konzumnich brambor. $\mathrm{PhD}$ thesis, $\mathrm{ZF} \mathrm{JU}$ in České Budějoivce. pp. 190.

Carver, J.D., 1994. Dietary nucleotides: cellular immune, intestinal and hepatic system effects. $J$. Nutri., 124: 144S-148S. https://doi.org/10.1093/ jn/124.suppl_1.144S

Chell, M., 1997. New developments in breadmaking. Fd. Manufact., 72: 21-22.

Chen, J. and Seviour, R., 2007. Medicinal importance of fungal $\beta$ - $(1 \rightarrow 3),(1 \rightarrow 6)$-glucans. Mycol. Res. 111: 635-652. https://doi.org/10.1016/j. mycres.2007.02.011

Cmiljanic, R., Lukic, M. and Trenkovski, S., 2001. The effect of Paciflor-C probiotic on gain, feed conversion and mortality of fattening chicks. Biotech. Anim. Husb., 17: 33-38

Cotter, P., Malzone, A., Paluch, B., Lilburn, M. and Sefton, A., 2000. Modulation of humoral immunity in commercial laying hens by a dietary prebiotic. Poult. Sci. 79: 38.

Curran, D.M., Tepper, B.J. and Montville, T.J., 1990. Use of bicarbonates for microbial control and improved water-binding capacity in cod fillets. J. Fd. Sci., 55: 1564-1566. https://doi. org/10.1111/j.1365-2621.1990.tb03569.x

Davis, C.Y. and Sell, J.L., 1989. Immunoglobulin concentrations in serum and tissues of vitamin A-deficient broiler chicks after Newcastle disease virus vaccination. Poult. Sci., 68: 136-144. https:// doi.org/10.3382/ps.0680136

Firon, N., Ofek, I. and Sharon, N., 1983. Carbohydrate specificity of the surface lectins of Escherichia coli, Klebsiella pneumoniae, and Salmonella typhimurium. Carbohydr. Res., 120: 235-249. https://doi.org/10.1016/0008-6215(83)88019-7

Fred, E. and Peterson, W., 1921. Fermentation process for the production of acetic and lactic acids from corncobs. Ind. Eng. Chem. Res. 13: 211-213. https://doi.org/10.1021/ie50135a010

Gad, A.S., Hasan, E. and Abd El Aziz, A., 2010. Utilization of Opuntia ficus indica waste for 
production of Phanerochaete chrysosporium bioprotein. Am. J. Sci., 6: 208-216.

Ghanem, K.M., El-Refai, A. and El-Gazaerly, M., 1986. Some fermentation parameters influencing single cell protein production by Saccharomyces uvarum Y-1347. Agric. Wastes, 15: 113-120. https://doi. org/10.1016/0141-4607(86)90042-9

Gueimonde, M. and Salminen, S., 2006. New methods for selecting and evaluating probiotics. Dig. Liver Dis., 38: S242-S247. https://doi.org/10.1016/S15908658(07)60003-6

Guimarães, T.M., Moriel, D.G., Machado, I.P., Picheth C.M. and Bonfim, T., 2006. Isolation and characterization of Saccharomyces cerevisiae strains of winery interest. Rev. Bras. Cienc. Farm. 42: $119-126 . \quad \mathrm{https}: / /$ doi.org/10.1590/S151693322006000100013

Haddadin, M.S., Abdulrahim, S.M., Al-Khawaldeh, G.Y. and Robinson, R.K., 1999. Solid state fermentation of waste pomace from olive processing. J. Chem. Technol. Biotechnol., 74: 613-618. https://doi.org/10.1002/(SICI)10974660(199907)74:7<613::AID-JCTB80>3.0.CO;2-8

Jalasutram, V., Kataram, S., Gandu, B. and Anupoju, G.R., 2013. Single cell protein production from digested and undigested poultry litter by Candida utilis: Optimization of process parameters using response surface methodology. Clean. Technol. Envir., 15: 265-273. https://doi.org/10.1007/s10098012-0504-3

Jamuna, R. and Ramakrishna, S.V., 1989. SCP production and removal of organic load from cassava starch industry waste by yeasts. J. Ferm. Bioeng., 67: 126131.https://doi.org/10.1016/0922-338X(89)90193-1

Khan, F.A., Bacha, N., Khan, S., Haleem, L. and Alam, W., 2016. Optimization of laboratory requirements through experimental design for the production of indigenous saccharomyces cerevisiae from orange peels. J. Sci. Tech. Univ. Peshawar, 40: 01-07.

Khan, F.A., Khan, S., Bacha, N. and Khan, T., 2018. Optimization of laboratory requirements through experimental design for maximum growth of indigenous saccharomyces cerevisiae using apple waste as substrate. Int. J. Biosci., 12: 136-142. https://doi.org/10.12692/ijb/12.1.136-142

Kihlberg, R., 1972. The microbe as a source of food. Annu. Rev. Microbiol., 26: 427-466. https://doi. org/10.1146/annurev.mi.26.100172.002235

Klis, F.M., Mol, P., Hell, K. and Brul, S., 2002. Dynamics of cell wall structure in Saccharomyces cerevisiae. FEMS Microbiol. Rev., 26: 239-256. https://doi. org/10.1111/j.1574-6976.2002.tb00613.x
Kurtzman, C., Fell J.W. and Boekhout. T., 2011. The yeasts: A taxonomic study. Elsevier.

Laegreid, W. and Bauer. N., 2004. Probiotics for pathogen control in poultry and livestock. American Meat Science Association Conference Reciprocal Proceedings.

Lenihan, P., Orozco, A., Neill, E.O., Ahmad, M., Rooney, D. and Walker, G., 2010. Dilute acid hydrolysis of lignocellulosic biomass. J. chem. Eng., 156: 395403. https://doi.org/10.1016/j.cej.2009.10.061

Line, J.E., Bailey, J.S., Cox, N.A., Stern. N.J. and Tompkins. T., 1998. Effect of yeast-supplemented feed on Salmonella and Campylobacter populations in broilers. Poul. Sci., 77: 405-410. https://doi. org/10.1093/ps/77.3.405

Lowry, O.H., Rosebrough, N.J., Farr, A.L. and Randall, R.J., 1951. Protein measurement with the Folin phenol reagent. J. biol. Chem. 193: 265-275.

Lyutskanov, N., Koleva, L., Stateva, L., Venkov, P. and Hadjiolov, A., 1990. Protein extracts for nutritional purposes from fragile strains of Saccharomyces cerevisiae: Reduction of the nucleic acid content and applicability of the protein extracts. J. Basic Microbiol., 30: 523-528. https://doi.org/10.1002/ jobm.3620300713

Magnani, M., Castro-Gomez, R.J.H., Mori, M.P., Kuasne, H., Gregório, E.P., Libos F. and Cólus I.M., 2011. Protective effect of carboxymethyl-glucan (CM$\mathrm{G})$ against DNA damage in patients with advanced prostate cancer. Genet. mol. Biol. 34: 131-135. https://doi.org/10.1590/S1415-47572010005000103

Nasseri, A., Rasoul-Amini, S., Morowvat, M. and Ghasemi, Y., 2011. Single cell protein: production and process. Am. J. Fd. Technol., 6: 103-116. https:// doi.org/10.3923/ajft.2011.103.116

Nofemele, Z., Shukla P., Trussler, A., Permaul, K. and Singh, S., 2012. Improvement of ethanol production from sugarcane molasses through enhanced nutrient supplementation using Saccharomyces cerevisiae. J. Brew. Distilling, 3: 29-35.

Ochei, J. and Kolhatkar, A., 2000. Medical laboratory science: Theory and practice. Department of Microbiology, College of Medicine, Sultan Qaboos University, Muscat, pp. 1072.

Ojokoh, A. and Uzeh, R., 2005. Production of Saccharomyces cerevisiae biomass in papaya extract medium. Afr. J. Biotechnol., 4:1281-1284.

Oyofo, B., DeLoach, J., Corrier, D., Norman, J., Ziprin, R. and Mollenhauer, H., 1989a. Prevention of Salmonella typhimurium colonization of broilers with D-mannose. Poult. Sci., 68: 1357-1360. https:// doi.org/10.3382/ps.0681357 
Oyofo, B., Droleskey, R., Norman, J., Mollenhauer, H., Ziprin, R., Corrier, D. and DeLoach, J., 1989b. Inhibition by mannose of in vitro colonization of chicken small intestine by Salmonella typhimurium. Poult. Sci., 68: 1351-1356. https://doi.org/10.3382/ ps.0681351

Patterson, J. and Burkholder, K., 2003. Application of prebiotics and probiotics in poultry production. Poult. Sci., 82: 627-631. https://doi.org/10.1093/ ps/82.4.627

Paul, D., Mukhopadhyay, R., Chatterjee, B.P. and Guha, A.K., 2002. Nutritional profile of food yeast Kluyveromyces fragilis biomass grown on whey. Appl. Biochem. Biotechnol., 97: 209-218. https:// doi.org/10.1385/ABAB:97:3:209

Qureshi, S.K., Masud, T. and Sammi, S., 2007. Isolation and taxonomic characterization of yeast strains on the basis of maltose utilization capacity for bread making. Int. J. Agric. Biol., 9: 110-113.

Raju, M. and Devegowda, G., 2000. Influence of esterified-glucomannan on performance and organ morphology, serum biochemistry and haematology in broilers exposed to individual and combined mycotoxicosis (aflatoxin, ochratoxin and T-2 toxin). Br. Poult. Sci., 41: 640-650. https://doi. org/10.1080/713654986

Ravindra, P., 2000. Value-added food: Single cell protein. Biotechnol. Adv., 18: 459-479. https://doi. org/10.1016/S0734-9750(00)00045-8

Saima, M., Akhter, M. and Khan, U., 2008. Investigation on the availability of amino acids from different animal protein sources in golden cockerels. J. Anim. Pl. Sci. 18: 53-56.

Santin, E., Maiorka, A., Macari, M., Grecco, M., Sanchez, J., Okada T. and Myasaka, A., 2001. Performance and intestinal mucosa development of broiler chickens fed diets containing Saccharomyces cerevisiae cell wall. J. appl. Poult. Res. 10: 236-244. https://doi.org/10.1093/japr/10.3.236

Shashidhara, R. and Devegowda, G., 2003. Effect of dietary mannan oligosaccharide on broiler breeder production traits and immunity. Poult. Sci., 82: 1319-1325. https://doi.org/10.1093/ps/82.8.1319

Son, H.S., Kim, K.M., Van Den Berg, F., Hwang, G.S., Park, W.-M., Lee, C.-H. and Hong, Y.-S., 2008. $1 \mathrm{H}$ nuclear magnetic resonance-based metabolomic characterization of wines by grape varieties and production areas. Agricult. Fd. Chem., 56: $8007-$ 8016. https://doi.org/10.1021/jf801424u

Šuranská, H., Vránová, D. and Omelková, J., 2016. Isolation, identification and characterization of regional indigenous Saccharomyces cerevisiae strains. Braz. J. Microbiol., 47: 181-190. https://doi. org/10.1016/j.bjm.2015.11.010

Talebnia, F. 2008. Ethanol production from cellulosic biomass by encapsulated Saccharomyces cerevisiae. Chalmers University of Technology, Dep. of Chemical and Biological Engineering.

Tannenbaum, S.R. and Wang, D.I., 1975. Single-cell protein II. MIT Press.

Van Leeuwen, P., Verdonk, J. and Kwakernaak, C., 2005. Effects of fructo oligo saccharide (OF) inclusion in diets on performance of broiler chickens. Confid. Rep., 5: 100650.

Walker, G.M., 1998. Yeast physiology and biotechnology. John Wiley \& Sons.

Wolf, J., Bindraban, P., Luijten, J. and Vleeshouwers, L., 2003. Exploratory study on the land area required for global food supply and the potential global production of bioenergy. Agric. Syst., 76: 841-861. https://doi.org/10.1016/S0308-521X(02)00077-X

Woodward, C., Henderson J.W. and Wielgos, T., 2007. High-speed amino acid analysis (AAA) on $1.8 \mu \mathrm{m}$ reversed-phase $(R P)$ columns. Agilent Technologies, Wilmington, DE, USA. 